\title{
Pharmacognostic study of Sphaeranthus indicus Linn.: A Review
}

\author{
Sonia Singh*, Bhupesh C. Semwal, Dr. Prabhat Kr Upadhaya
}

Sonia Singh*, Bhupesh C. Semwal, Prabhat Kr Upadhaya

GLA University, Mathura, INDIA.

\section{Correspondence}

Sonia Singh

GLA University, Mathura, INDIA.

E-mail: sonia.singh@gla.ac.in

History

- Submission Date: 23-07-2019;

- Review completed: 05-08-2019;

- Accepted Date: 23-08-2019.

\section{DOI : 10.5530/pj.2019.11.213}

Article Available online http://www.phcogj.com/v11/i6

\section{Copyright}

(C) 2019 Phcogj.Com. This is an openaccess article distributed under the terms of the Creative Commons Attribution 4.0 International license.

\begin{abstract}
Sphaeranthus indicus Linn. has the vernacular name of, "Mundi" and "East Indian globethistle, family Asteraceae. It is a spreading aromatic herb. It is indigenous at Rater of Chhindwara District, M.P and even found in most of the moist damp places of tropical zones of Garhwal Himalaya. The herbs contain a deep cherry coloured essential oil and a bitter alkaloid Sphaeranthine. It also contains many other active ingredients, namely, eudesmenolide-7 $\alpha$ hydroxy eudesm-4-en-6, 12-olide, 2-hydroxycostic acid, $\beta$-eudesmol, ilicic acid, methychavicol, $\alpha$-ionone, $d$-cadinene, $\alpha$-terpinene, citral, geraniol, geranyl acetate, sphaerene, indicusene and sphaeranthol. The herb has been investigated for many diseases and used in ethnomedicne. The review of this medicinal plant can revealed some important and valuable information with respect to pharmacognostical, phytochemical and pharmacological aspects. The main objective of this paper is to gather some valuable information with respect to its standardization, which has been done along with active ingredients by some researchers.

Key Words: S. indicus, Mundi, Gorakhmundi, Flavonoids, Alkaloids, Pharmacological uses, Ethnomedicine.
\end{abstract}

\section{INTRODUCTION}

Sphaeranthus indicus Linn, commonly known as Gorakhmundi, is a spreading aromatic herb, distributed throughout in India upto $1500 \mathrm{~m}$ from Kumaon hills to Sikkim on the Himalayas chiefly on damp habitats. ${ }^{1}$ It is used in the treatment of various diseases, such as, dysentery, epileptic, leucoderma, urinary discharges, insanity, anthelmintic. ${ }^{2}$ In this present paper, the author aims to provide informative review about the plant on morphology, microscopy, phtyochemisty and pharmacology with some new informative aspects.

\section{Biological source 3}

Botanical Name: Sphaeranthus indicus Linn.

Synonym: Sphaeranthus hirtus Willd, Sphaeranthus mollis Roxb.

Family: Asteraceae ( Compositae)

\section{Vernacular names2,3}

Sanskrit: Mundi, Sravani, Bhumikadamba

Assamese: Kamadarus

Bengali: Surmuriya, Mudmudiya

English: East Indian globe-thistle

Gujrati: Gorakhmundi

Hindi: Mundi, Gorakhmundi

Kannada: Mudukattanagida, Karande

Malayalam: Manni

Marathi: Mundi, Gorakhmundi

Oriya: Bhuikadam

Punjabi: Gorakhmunda

\section{Tamil: Karandai}

Telugu: Bodasarumu Badataramu

Urdu: Mundi

Beng: Chagulnadi

\section{Taxonomic Classification4}

Kingdom: Plantae

Subkingdom: Viridaeplantae

Phyllum: Tracheophyta

Subphyllum: Euphyllophytina

Infraphyllum: Radiatopses

Class: Magnoliopsida

Subclass: Asteridae

Superorder: Asteranae

Order: Asterales

Family: Asteraceae

Genus: Sphaeranthus

Species: indicus

\section{Occurrence and distribution}

It is widely occurring at Rater of Chhindwara district, M.P. It is also found in the moist damp places of tropical zones of Garhwal Himalaya. ${ }^{5}$

\section{Macroscopic study}

It is an annual, prostrate-decumbent, procumbentascending, glandular, villous, tomentose, aromatic herbs, a height of $30-60 \mathrm{~cm}$. Stems are narrowly winged along with wing toothed. Leaves are sessile, 2.5-5 x1.5-2 cm, obovate-oblong, acute to rounded at tip, glandular-villous on both surfaces; apex are

Cite this article: Singh S, Semwal BC, Kr Upadhaya P. Pharmacognostic study of Sphaeranthus indicus Linn.: A Review. Pharmacog J. 2019;11(6):1376-85 
lanceolate, oblong or oblong -spathulate, obtuse-mucronate; base are semi-amplexicaul; margin are acutely serrate, double dentate at some places, presence of glands and sessile; Peduncles are 2-6 cm long which are glandular and pubescent, with a compound purple head. Flowers are in globular shape, composed of capitula $13 \mathrm{~mm}(\mathrm{~d})$, globose or ellipsoid and purplish in color with involucral bracts, in which outer bracts having capitula $3 \mathrm{~mm}$ long, linear, apiculate, ciliate and glandular whereas inner bracts- capitula $3 \mathrm{~mm}$ long, linear-oblanceolate and acuminate. ${ }^{6}$ Flowers and Fruits are matured during March-June. ${ }^{7}$

\section{Microscopic study}

Root: Epidermis is a single layered, rectangular cell followed by secondary cortex composed of oval to tangentially elongated, thin walled, parenchymatous cells having aerenchyma. The secondary phloem consists of thin walled, oval to polygonal cells, presence of large number of scattered lignified phloem fibers. The central portion is occupied by lignified, secondary xylem containing vessels which are pitted, presence of simple starch grains, round to oval with concentric striations and distinct hilum of 13 to $27 \mu$ (d) present in the secondary cortex.

Stem: Epidermis consists of a single layered cell covered with thick cuticle The cortex composed of 4 to 6 layers of oval -polygonal, thin walled, parenchymatous cells. The endodermis is a single layered consists of barrel shaped cells, followed by lignified pericyclic fibers arranged in discontinuous ring. The secondary phloem containing groups of cellulosic fibers which are scattered in this zone. The secondary xylem composed of spiral thickening or simple pitted vessels. Pith is present in a very wide portion, composed of oval to polygonal, and thin walled parenchymatous cells.

Leaf: It consists of lower epidermis, mesophyll and upper epidermis. Epidermis is a single layered, followed by 4 to 6 layered thin strips of collenchymas and 3 to 4 layered parenchyma cells, present on both surfaces. Glandular trichomes composed of 2 or 3 cells high, uni or biseriate stalk, having a multicellular head whereas uniseriate covering trichomes with 2 to 5 cells are present on both surfaces. Mesophyll composed of oval to polygonal thin walled parenchymatous cells. Presence of anisocytic stomata present on both surfaces.

\section{Powder characteristics}

Powder is greyish yellow in colour. Microscopically, it shows the presence of oval to polygonal thin walled fragments of aerenchyma cells and thin walled, elongated epidermal cells. Occasionally, glandular trichomes and anisocytic stomata are seen. Presence of vessels with spiral and pitted thickening. Fibers are short with thick walled, lignified along with wide lumen and blunt tips having a small pits. Starch grains are simple, oval to round, elliptical in shape with centric hilum and striations are present ${ }^{8}$ (Morphology and Microscopy as shown in Figure 1-4. ${ }^{9,10}$ ).

\section{Medicinal properties and uses}

- Herb is generally used as tonic, deobstruent, alternative, aphrodisiac ${ }^{11}$; used in nervous debility as well as in eye troubles. Seeds are useful in asthma, bronchitis, cough, fever, perttusis and decoction used in insomnia. ${ }^{12}$

- Decoction of herb is used in cough and other chest related troubles; and also credited with antituberculosis properties Herb is also used as a fish-poison and it is stuffed into holes of crabs to kill them Even leaves are eaten as a pot-herb. ${ }^{13}$

- A paste of the herb mixed with oil is good in painful swellings and pruritus. It is also useful in strangury, diabetes, leprosy, fever, cough, pectoralgia, cough, gastropathy, hernia, haemorrhoids, helminthiasis and dyspepsia. Oil prepared from root is useful in scrofula. The powdered leaves are good for skin diseases and are considered as a nervine tonic. ${ }^{3}$

- Root isacrid, bitter and sweet in taste and highly efficacious as diuretic, febrifuge, expectorant and stomachic.

- Root bark are ground into powder, is a valuable remedy in bleeding piles; also used as paste for local application.

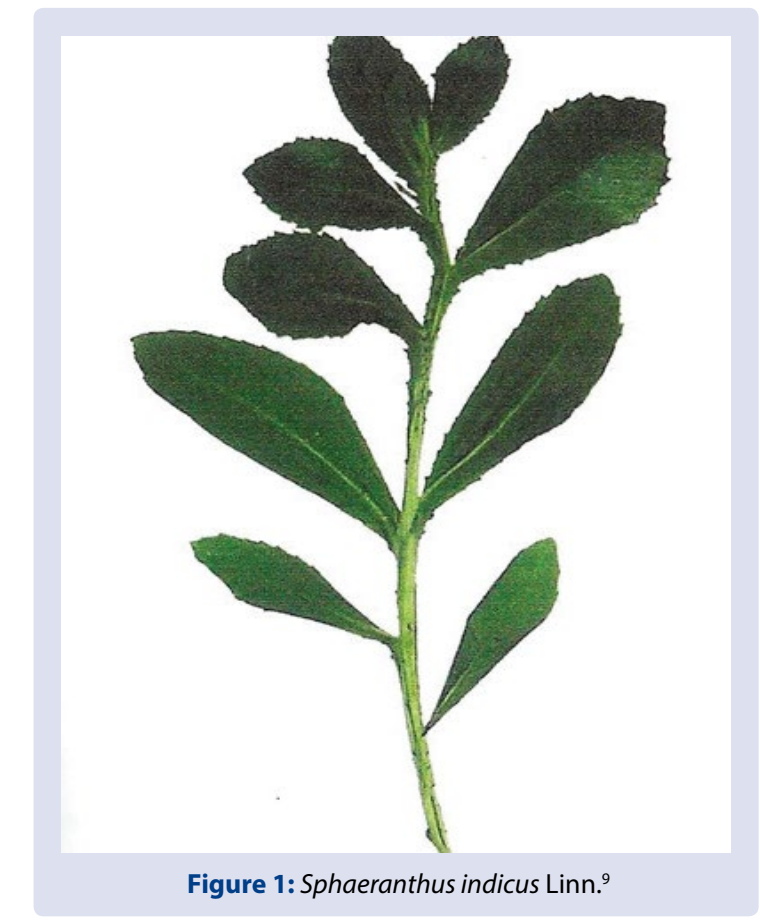




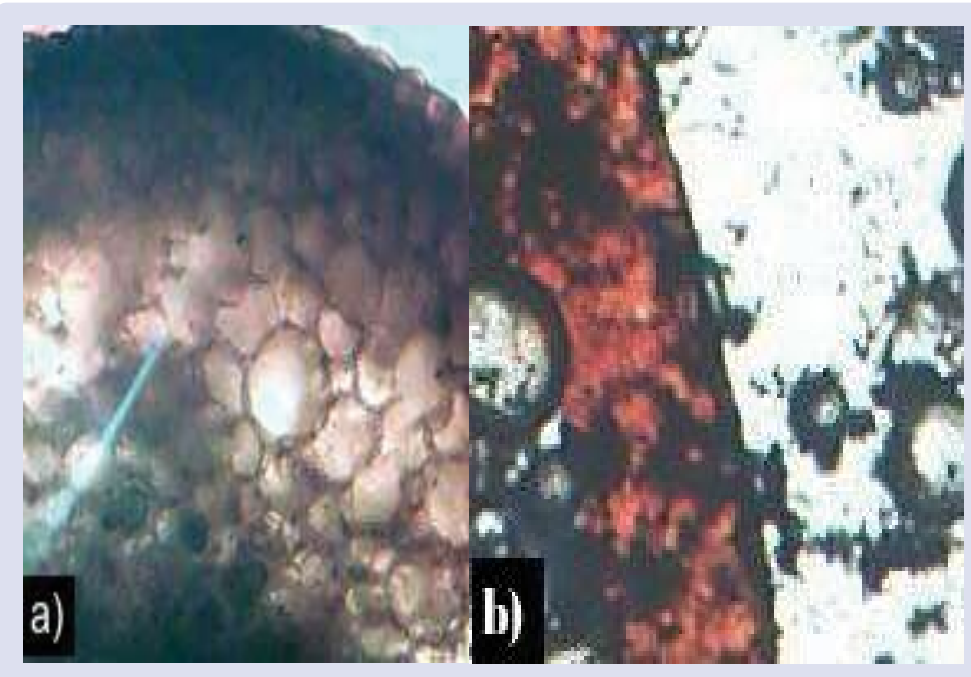

Figure 2: Microscopy of root of S. indicus. ${ }^{10}$

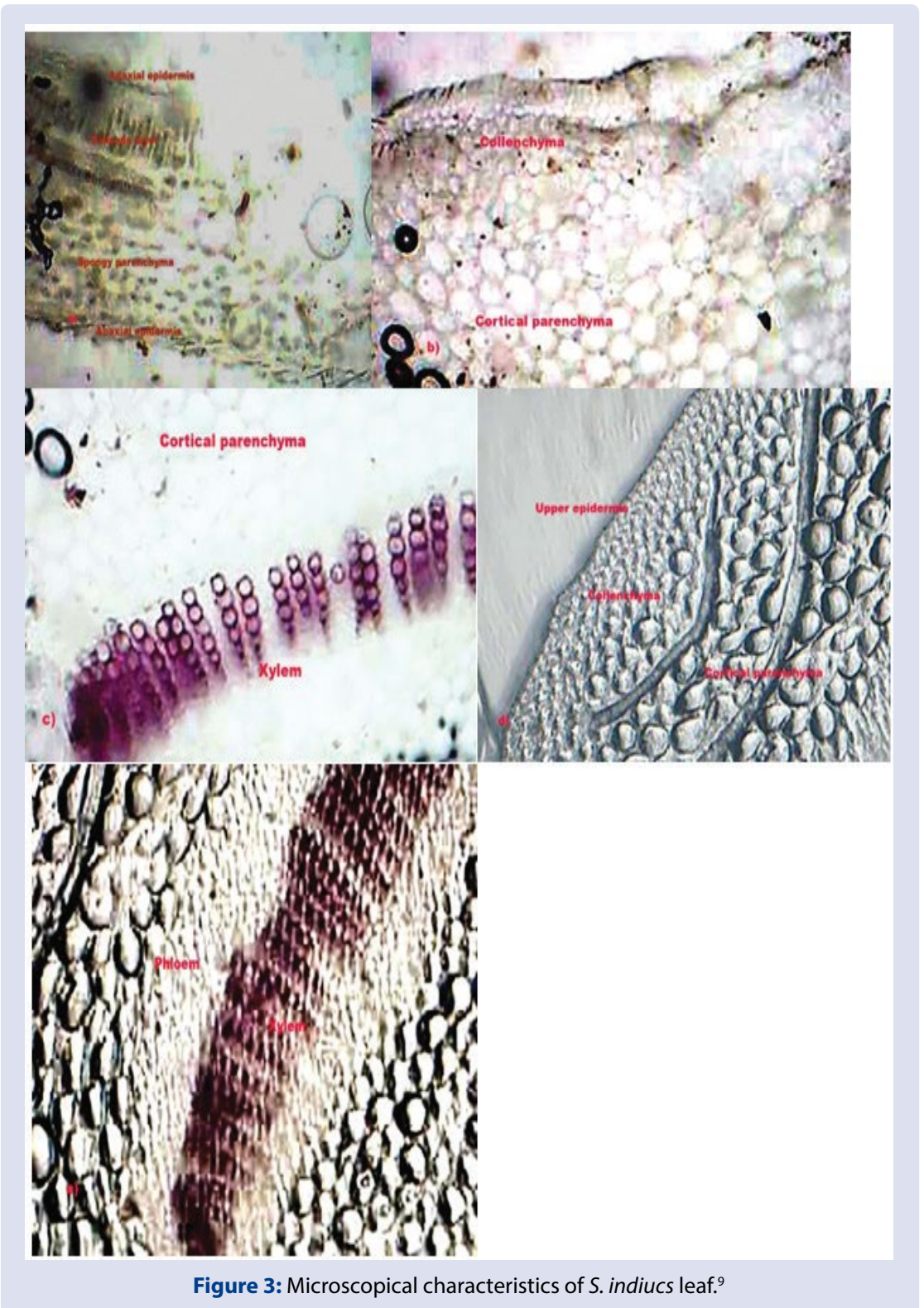




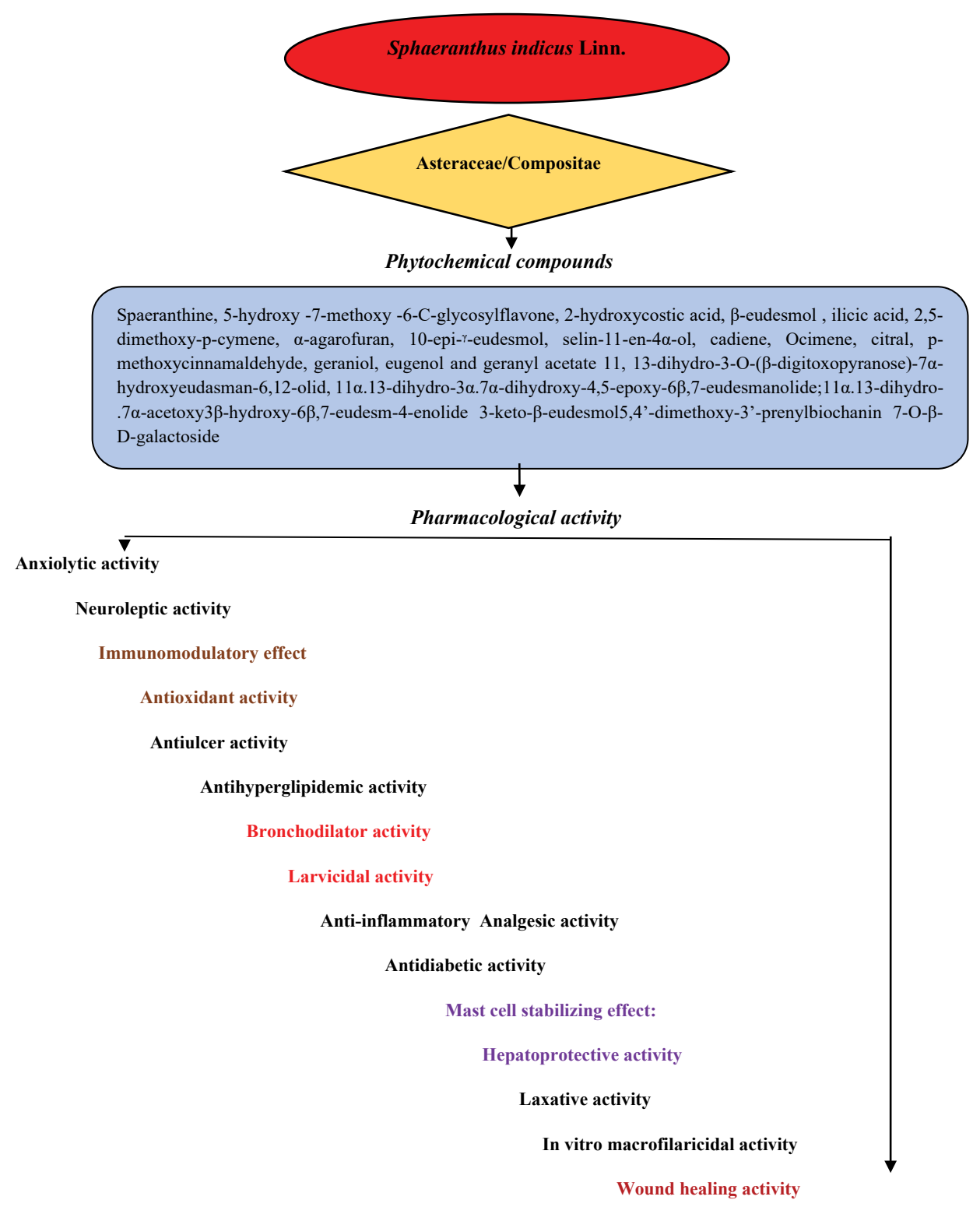

Antimicrobial activity

Anti-ulcer activity

Figure 4: Schematic flow chart representation : A summary on Sphaeranthus indicus Linn.

- Flowers (flower heads) are highly esteemed as alternatives, depuratives, refrigerants, tonics and blood -purifiers in skin diseases. ${ }^{14}$ They are swallowed to cure conjunctivitis. ${ }^{15}$

\section{Ethnobotanical uses}

- The plant with cumin is useful in stomachic; with honey it is given for cough; and ground with oil, it is used to cure itch. The bark of the young plant is made into a kind of confection by ribbing it up with clarified butter, flour and sugar; a portion of this taken daily is said to be a good tonic, and to prevent the hair turning white or falling off. 12

- Leaves are dried in the shade and powdered are used in doses of 20 grains twice a day in chronic skin diseases as antisyphilitic and nervine tonic. Root is used as a stomachic and anthelmintic in doses of about 40 grains daily in the form of powder.14
- Decoction of the whole plant is used as diuretic in urethral discharge. 15

- An oil prepared from the root, by steeping it in water, and then boiling in oil of sesamum until all the water is expelled, taken fasting every morning for 41 days in doses of 2 dirhems, is said to be a powerful aphrodisiac in the neck with benefits and also a good remedy in jaundice.16

\section{Phytochemistry}

A novel flavonoid C-glycoside 5-hydroxy -7-methoxy -6-C-glycosylflavone was isolated from the aerial part of the plant. ${ }^{17}$ An alkaloid, Spaeranthine and volatile oil by steam distillation, isolated from the S, indicus. ${ }^{18} 7 \alpha$-hydroxyeudesm-4-en-6,12olide(sesquiterpene lactone), 2-hydroxycostic acid ( sesquiterpene acid), $\beta$-eudesmol and ilicic acid have been isolated from the 
acetone extract of S.indicus. The hydrodistilled essential compound, 2,5-dimethoxy-p-cymene (18.2\%), a-agarofuran (11.8\%), 10-epi- $\gamma_{-}$ eudesmol (7.9\%) and selin-11-en-4a-ol (12.7\%) were isolated and identified by GC and GC/MS. ${ }^{19}$ Essential oil to the tune of $0.06-0.08 \%$ obtained from the capitula of S.indicus. ${ }^{20}$ The major constituents were cadiene. Ocimene, citral, p-methoxycinnamaldehyde, geraniol, eugenol and geranyl acetate. ${ }^{21} \mathrm{~A}$ bicyclic sesquiterpene lactone has been isolated from the petroleum ether extract of the aerial part of the plant and found to possess strong antimicrobial activity against Staphylococcus aureus, S. albus, E. coli, Fusarium species, Helminthosporium species. ${ }^{22}$ Two new eudesmanolides, 11a13-dihydro-3a,7a-dihydroxyeudesm-4en-6a,12-olide and 4-en-6 $\beta, 7 \alpha$-eudesmanolide, isolated from the aerial part of S. indicus. ${ }^{23} 11 \alpha, 13$-dihydro-3a,7 $\alpha$-dihydroxyfrullanolide and $2 \alpha$-hydroxycostic acid, a new eudesmanolide isolated from the aerial part of the plant.7-hydroxyeudesmanolides ${ }^{24}$ and two sesquiterpenoids, cryptomeridiol , 4-epicryptomeridiol isolated from the plant. ${ }^{25}$

A new antifungal eudesmanolide glycoside 11, 13-dihydro-3-O( $\beta$-digitoxopyranose)-7 $\alpha$-hydroxyeudasman-6,12-olide has been isolated. ${ }^{26} \quad 11 \alpha .13$-dihydro-3a.7 $\alpha$-dihydroxy-4,5-epoxy- $6 \beta, 7$ eudesmanolide; $11 \alpha .13$-dihydro-.7 $\alpha$-acetoxy $3 \beta$-hydroxy- $6 \beta, 7$-eudesm4-enolide ${ }^{27}$ and 3-keto- $\beta$-eudesmol5,4'-dimethoxy-3'-prenylbiochanin 7-O- $\beta$-D-galactoside, a new isoflavone glycoside isolated from the leaves of S.indicus. ${ }^{28} 7$-hydroxyfrullanolide, an antimicrobial sesquiterpene lactone isolated from S.indicus Linn. ${ }^{29}$ Methyl chavicol, a-ionone, d-cadiene, p-methoxycinnmaldehyde, $\alpha$-terpinene, citral, geraniol, geranyl acetate, $\beta$-ionoe, sphaerene, indicusene, sphaeranthol as essential oil and $\beta$-sitosterol, n-triacontanol, phenyl urethane, $\mathrm{n}$-pentacosane isolated from the oil. ${ }^{30}$

\section{Pharmacological activity}

Anxiolytic activity: At doses of 200 and $500 \mathrm{mg} / \mathrm{kg}$,p.o., the hydroalcoholic extract of Sphaeranthus indicus.

resulted in decrease in locomotor activity and central nervous depressant activity in mice. It also increased the immobility time in the forced swimming test at an oral dose of $500 \mathrm{mg} / \mathrm{kg}$ but did not significantly modify the activity in tail suspension test. The same doses of SIE were used to protect rats against MES-induced convulsions and mice against PTZ-induced convulsions. ${ }^{31}$ In other study, the petroleum ether extract of flowers of S.indicus Linn. has been found to possess significant result against anxiolytic activity than ethanolic or water extracts but was less as compared to diazepam $(1 \mathrm{mg} / \mathrm{kg}){ }^{32}$

Neuroleptic activity: Neuropharmacological effects of the hydroalcoholic extract of S.indicus (100, 200 and $500 \mathrm{mg} / \mathrm{kg}$,p.o.) were studied against spontaneous motor activity, pentobarbital-induced sleeping time, motor coordination and exploratory behavior in mice, in which significant results were observed .It also antagonized apomorphine-induced stereotypy in mice, produced catalepsy and also potentiated haloperidol-induced catalepsy in rats. ${ }^{33}$ In other study, the petroleum ether, methanol and aqueous extracts at 100, 200 and $400 \mathrm{mg} / \mathrm{kg} / \mathrm{p}$.o showed significant results in various models like motor coordination, locomotor activity, cognitive behavior, anxiety, haloperidol induced catalepsy, sodium nitrite induced respiratory arrest, hypoxia stress induced neurotoxicity and convulsion induced by pentylenetetrazol and maximum electroshock. ${ }^{34}$ The plant proved to possess anticonvulsant, anxiolytic and antistress activity. ${ }^{35}$ Ethanolic root extract at 200 and $400 \mathrm{mg} / \mathrm{kg}$,i.p significantly reduced the duration of seizures produced by maximal electroshock and delayed the latency of seizures produced by pentylenetrtrazole and picrotoxin. ${ }^{36}$

Immunomodulatory effect: The petroleum ether extract from the flower heads of S.indicus was found to be effective in increasing phagocytic activity, hemagglutination antibody titer and delayed type hypersensitivity in mice at a dose of $200 \mathrm{mg} / \mathrm{kg} .{ }^{37}$ In other study, the methanolic extract of S.indicus (100, 200 and $400 \mathrm{mg} / \mathrm{kg}$ )(MESI) was evaluated for immunomodulatory activity (humoral immunity and cellular immunity) with antigen challenge by sheep RBCs in healthy wistar albino rats. The dose of $100 \mathrm{mg} / \mathrm{kg}$ b.w of extract showed significant increase in the circulating antibody titer and the number of plaque forming cells in the spleen as compared to 200 and $400 \mathrm{mg} / \mathrm{kg} \mathrm{b.w.}{ }^{38} \mathrm{It}$ was also found that MESI showed significant increase in the Delayed type hypersensitivity (DTH) response, restoration of histological parameters, and increase in lymphocytes and rosettes formation in T-cell population at dose of $400 \mathrm{mg} / \mathrm{kg}$ b.w. Even immunomodulatory activity of herbal formulation containing methanolic extracts of flower heads of S.indicus, rhizomes of Curculigo orochioides and fruits of Piper nigrumwas also studied on humoral (Haemagglutination antibody titre) and cellular immunity (Delayed type hypersensitivity)in mice. ${ }^{39}$ Sphaeranthanolide, a new sesquiterpene glycoside, isolated from the flowers of S.indicus exhibited immune stimulating activity. ${ }^{40}$

Antioxidant activity: The methanol extracts obtained from leaf, flower, stem, root of S.indicus were evaluated for antioxidant (using DPPH, Hydroxyl radical, Nitric oxide, Superoxide anion and Hydrogen peroxide assay) and antibacterial activity. The flower extract and leaf extract were exhibited highest scavenging activity at $150 \mu \mathrm{g} / \mathrm{ml}$ concentrations and all the extracts of S.indicus produced minimum zones of inhibitions against human pathogenic species. ${ }^{41}$ In other study, the ethyl acetate extract showed significant reducing activity as compared to petroleum ether, chloroform and methanol extracts. The petroleum ether and chloroform extract exhibited significant activity against Klebsiella pneumoniae, Proteus mirabilis, Salmonella typhimurium and Staphylococcus epidermidis with MIC of $0.07 \mathrm{mg} /$ $\mathrm{ml}$ and $0.15-0.3 \mathrm{mg} / \mathrm{ml}$ respectively. Ethyl acetate extract showed significant activity with MIC of $0.07 \mathrm{mg} / \mathrm{ml}$ against K.pneumoniae whereas methanol extract exhibited moderate to least activity against test bacteria with MIC of $0.31-5 \mathrm{mg} / \mathrm{ml}^{42}$ The ethanolic extract of the root of S.indicus (EESIR) (100 and $200 \mathrm{mg} / \mathrm{kg}$ ) was also studied for antidiabetic, antihyperlipidemic and in vivo antioxidant activity in streptozotocin induced type (STZ-induced) 1 diabetic rats. It revealed significant reduction in blood glucose and increase in body weight in STZ-induced diabetic rats as compared to diabetic control rats. At a dose of $200 \mathrm{mg} / \mathrm{kg}$, the EESIR treatment in diabetic rats produced significant increase in superoxide dismutase (SOD), catalase (CAT), glutathione peroxidase (GPx) and decrease in thiobarbituric acid reactive substances (TBARS) levels as compared to diabetic control rats. ${ }^{43}$

Antiulcer activity: The ethanol extracts of S.indicus whole plant showed significant reduction in gastric volume, free acidity, total acidity and ulcer index at $250 \mathrm{mg} / \mathrm{kg}$ and $500 \mathrm{mg} / \mathrm{kg}$ b.w .The ulcer protection activity of the extract was found to be $82.9 \%$ and $85.3 \%$ as compared to the standard drug ranitidine $92.6 \%$ and proved to possess significant dose dependent anti-ulcer activity. ${ }^{44}$

Antihyperglipidemic activity: The alcoholic extract of flower heads of S.indicus was investigated in atherogenic diet induced hyperlipidemia and showed significant increase in the level of high-density lipoprotein after eight days of $500 \mathrm{mg} / \mathrm{kg}$ of drug, p.o, daily proving its potential protective role in atherosclerosis. ${ }^{45}$

Bronchodilator activity: The methanolic extract of S.indicus Linn showed significant protection $(p<0.001)$ against histamine induced acute bronchospasmin in guinea pigs as compared to its various fractions. ${ }^{46}$

Larvicidal activity: The four different extracts (hexane, diethyl ether, dichloromethane and ethyl acetate ) of seven plants containing leaves of Abutilon indicum, Cleistanthus collinus, leucas aspera, Murraya koenigii, Hyptis suaveolens, Citrullus colocynthis and Sphaeranthus indicus were investigated and found to be effective against the early third instar 
larvae of Anopheles stephensi. Similarly, the leaf extracts of S.indicus, Cleistanthus collinus and Murraya koenigii were also investigated against the third instar larvae of Culex quinquefasciatus at 250, 500, 750 and $1000 \mathrm{ppm}$ respectively and showed significant mortality of filarial vector. $^{47,48}$

Anti-inflammatory and analgesic activity: The anti-inflammatory activity of ethanolic extract of S.indicus was evaluated at a dose of 300 $\mathrm{mg} / \mathrm{kg}$ and $500 \mathrm{mg} / \mathrm{kg}$ by measuring the mean decrease in hind paw volume after the sub planter injection of carrageenan and found that at the end of one hour the inhibition of paw edema was 42.66 and $50.5 \%$ respectively. The analgesic activity was also studied against acetic acid induced writhing response showed the percentage of protection of 62.79 and $68.21 .^{49}$ Ethanolic extract of S.indicus at 100, 200 and $400 \mathrm{mg} / \mathrm{kg}$ exhibited dose dependent and significant anti-inflammatory activity in acute (carageenan induced hind paw edema) and chronic (cotton pellet granuloma formation ) model of inflammation in albino rats respectively. ${ }^{50}$ In other study, the ethanol and petroleum ether extracts showed significant effect at doses of 200 and $400 \mathrm{mg} / \mathrm{kg}$ against carrageenan induced acute inflammation, Formalin induced chronic inflammation and Cotton Pellet induced granuloma respectively. ${ }^{51}$ Methanol extract of S.indicus reduced aortic lesion area in high fat fed LDL mice and hyperlipidemic hamsters at $100,300 \mathrm{mg} / \mathrm{kg} /$ day and 200 $\mathrm{mg} / \mathrm{kg} /$ day by $22 \%$ and $45 \%$ respectively, but not able to altered the lipid profile in both animal models. The activity was comparable to that of a standard agent Fenofibrate decreased arotic lesions by $26 \%$ and $84 \%$ in LDL mice and hyperlipidemic hamsters, which was driven by massive reductions in proatherogenic lipoproteins. ${ }^{52}$ It has been found that petroleum ether, chloroform and ethanol extract showed significant analgesic activity at a dose of $200 \mathrm{mg} / \mathrm{kg}$ and $400 \mathrm{mg} / \mathrm{kg}$ in albino rats against Eddy's hot plate, Tail immersion and Brewer's yeast induced pyrexia method as compared to the standard diclofenac sodium drug respectively. ${ }^{53}$ The ethanol extracts of whole plant of S.indicus Linn. showed significant increase in activity and percentage protection at 250 $\mathrm{mg} / \mathrm{kg}$ and $500 \mathrm{mg} / \mathrm{kg}$ b.w. when used in tail immersion method in rat models. ${ }^{54}$

Antidiabetic activity: Oral administration of alcoholic extract of S.indicus for 15 days in rats resulted in significant decrease in blood glucose levels, increase in hepatic glycogen and plasma insulin levels and also showed significant improvement in oral glucose tolerance test , when compared to Glibenclamide as a reference standard drug. ${ }^{55}$ Ethyl acetate, methanol and hydroalcoholic extracts of S.indicus were found to be produced significant antihyperglyceamic activity in alloxan induced diabetic rats at a dose of $200 \mathrm{mg} / \mathrm{kg}$ when taken orally for 15days , using Glibenclamide as standard. The methanol extract significantly decreased the lipid peroxides and showed antioxidant activity ${ }^{56}$ Methanol extract of S.indicus at a dose of $300 \mathrm{mg} / \mathrm{kg} \mathrm{b.w}$ when given orally showed significant decrease in glycosylated hemoglobin(HbA1c), serum total cholesterol, triglyceride and markedly increased HDL cholesterol and magnesium levels. It also restored the altered body weight to near normal state. ${ }^{57}$ Oral administration of flower head petroleum ether extracts at a dose of $200 \mathrm{mg} / \mathrm{kg}$ found to show significant reduction in blood glucose level. ${ }^{58}$

Mast cell stabilizing effect: The ethanol extract at $150 \mathrm{mg} / \mathrm{kg}$ and 300 $\mathrm{mg} / \mathrm{kg}$ and ethyl acetate extract at $100 \mathrm{mg} / \mathrm{kg}, 150 \mathrm{mg} / \mathrm{kg}$ and $300 \mathrm{mg} /$ $\mathrm{kg}$ showed slightly better protection of mast cell degranulation $77-86 \%$ and stabilizing activity $77-88 \%$ as compared to standard drug Ketotifen $75 \%$ and $69 \%$ in sheep serum model respectively. ${ }^{59}$

Hepatoprotective activity: Ethanol extract obtained from aerial parts of S.indicus L. at $300 \mathrm{mg} / \mathrm{kg}$ was investigated for hepatoprotective activity against paracetamol induced liver damage in rats. It showed a significant protection and reduction in the serum markers. ${ }^{60}$.Protective effect of aqueous extract was evaluated at $400 \mathrm{mg} / \mathrm{kg}$ b.w in rats and showed significant reversal of all elevated serum enzyme like SGOT, SGPT, ALP, total protein and total bilirubin to normal state when compared to paracetamol induced liver toxicity. ${ }^{61}$ Methanol extract was investigated for its hepatoprotective and antioxidant activity against carbon tetrachloride induced liver damage in rats using Livomyn as reference drug. The biochemical parameters like ALT, AST, ALP SOD, CAT, GST levels were significantly reverted back to normal levels. ${ }^{62}$

Laxative activity: The oral administration of $2 \mathrm{~g}$ of S.indicus, three times a day for 40 days showed statistically significant improvement on various parameters like hard stool, incomplete evacuation, excessive staining, lower abdomen fullness and gas collection and proved to possess laxative activity. ${ }^{63}$

In vitro macrofilaricidal activity: The methanol extracts of some medicinal plants namely, Centratherum anthelminticum, Cedrus deodara, S.indicus and Ricinus communis were proved to possess in vitro macrofilaricidal activity at $1-10 \mathrm{mg} / \mathrm{ml}$ against worm motility assay in adult Setaria digitata, the cattle filarial worm. ${ }^{64}$

Wound healing activity: Herbal formulation comprises of $2 \% \mathrm{w} / \mathrm{w}$ alcoholic extract of flower head of S.indicus was found to possess wound healing property by providing better tissue formation and protection against microbial invasion. ${ }^{65}$ In vivo application of a cream containing ethanol extract of aerial parts of S.indiucs Linn. on the paravertebral area of six excised wounded models once a day for 15 days in guinea pigs showed significant increase in the rate of wound contraction and the period of epithelialization as compared to neomycin. ${ }^{66}$

Anti-ulcer activity: The ethanol extracts of S.indicus whole plant at $250 \mathrm{mg} / \mathrm{kg}$ and $500 \mathrm{mg} / \mathrm{kg}$ b.w showed significant reduction in gastric volume, free acidity, total acidity and ulcer index in aspirin plus pylorus ligation method. The ulcer protection of the extract was found to be $82.9 \%$ and $85.6 \%$ as compared to Ranitidine $92.6 \%$ as standard drug. ${ }^{67}$

Antimicrobial activity: $n$-hexane extract obtained from flowers and aerial parts of S.indicus showed minimum inhibitory concentration of 0.15 and $1.25 \mathrm{mg} / \mathrm{ml}$ against candida albicans, using broth micro dilution method at concentrations range from 5 to $0.039 \mathrm{mg} / \mathrm{ml}$ and revealed to possess antibacterial and antifungal activity. ${ }^{68}$ The leaves were screened for in vitro antibacterial activity by agar well diffusion assay and showed varying degrees of inhibition on tested microorganisms. ${ }^{69}$ Similarly, the ethanol leaf extract was evaluated for antimicrobial, antibacterial and antifungal activity using in vitro disc (concentration of 1.25, 2.5 and 5 $\mathrm{mg} / \mathrm{disc}$ ) and broth tube dilution method. It showed significant MIC of $0.5,2.5$ and $5 / \mathrm{ml}$ against B. subtilis and S.aureus whereas 0.5 and $5 / \mathrm{ml}$ against Candida and Aspergillus niger respectively. ${ }^{70}$ The plant extract showed significant inhibition zone against E. coli, Klebsiella pneumonia, Proteus mirabils, Pseudomonas aerginosa and Acetobector .The activity was compared with Kanamycin as standard drug. ${ }^{71} \mathrm{~A}$ new eudesmanolide glycoside 11, 13-dihydro-3-O-( $\beta$-digitoxopyranose)$7 \alpha$-hydroxyeudasman-6,12-olide isolated from $S$.indicus Linn proved to possess antifungal activity. ${ }^{72}$ The methanol extract possess significant inhibitory effect $(65 \%$ at $p<0.05)$ against Microsporum gypseum when compared to positive control Ketaconazole (49\%) at $0.1 \mathrm{~g} / \mathrm{ml}$ concentration. ${ }^{73}$

Antidiarrhoeal activity: The ethanol and aqueous extracts showed significant anti diarrhoeal and antienteropooling activity at a dose of 200 and $400 \mathrm{mg} / \mathrm{kg}$. It showed decrease in propulsion of charcoal meal through the gastrointestinal tract significantly and inhibited the PGE2 induced intestinal fluid accumulation. ${ }^{74}$

S.indicus was found to be claimed as skin disease preventive plant. ${ }^{75}$

Anticancer activity: The petroleum ether extract induced apoptosis through the mitochondrial -dependent pathway in HL-60 cells when determined by sulfohodamine $\mathrm{B}$ assay. $\beta$-sitosterol and 
7-hydroxyfrullanolide isolated from S.indicus are considered to be potent anticancer compound. ${ }^{76}$

\section{Traditional system of medicine}

In siddha system of medicine, $S$. indicus is used in the name of Kottaikkarantai. It is used as one of the ingredients in the siddha preparation, "Veezhi Ennai (or Veezhi oil)."

\section{Important ayurvedic formulations}

Navaratnarāja, Mṭgānka Rasa, Arka Muț̣ị, Guduchyadi taila, Vatagajankusha rasa, Munditika churna, Guduchi taila.

\section{Ayurvedic therapeutic uses}

Ganțamālā, Apaci, Kuțțha, Kṭmi, Pāț̣u, Slipada, Medaroga, Apasmara, Kasa, Mutrakrcchra, Tvaka Roga, Stana Saithalya, Yonirogā, Āmātisara, Āmaroga, Vātaroga, Gudaroga, Plīhāroga, Chardi, Āmavāta, Gātradurgandhya, Sūryāvarta, Ardhāvabhāvabhedaka.

Dose: 3-6 g of the drug. ${ }^{77}$

\section{CONCLUSION}

From the literature survey, it is proved that the plant, Sphaeranthus indicus Linn. has been evaluated for phytochemical compounds and pharmacological activities. However, the plant has wide range of therapeutic uses; therefore, more clinical and pharmacological studies should be conducted to consider in new drug formulations.

\section{ACKNOWLEDGMENTS}

The author gratefully appreciates the support provided by Mr. Bhupesh C. Semwal and Dr Prabhat Kr. Upadhyay GLA University, Mathura, for giving the valuable time while expressing their views and useful opinions.

\section{AUTHORS CONTRIBUTION}

Sonia Singh wrote the manuscript. The rest of the coauthors has commented and discussed their opinions with the same. And then it has been reframed and finalized into comprehensive mode.

\section{CONFLICTS OF INTEREST}

There is no conflict of interests with the publication of this review paper.

\section{ABBREVIATIONS}

ALT: Alanine aminotransferase; AST: Aspartate aminotransferase; ALP: Alkaline phosphate; b.w: Body weight; CAT: Catalase; $\mathrm{cm}$ : Centimeter; d: Diameter; DPPH: 2,2-diphenyl-1-picrylhydrazyl; GC: Gas chromatograpghy; GST: Glutathione S-transferase; HDL: High density lipoproteins; ip: Intraperitoneal; kg: Kilogram; LDL: Lowdensity lipoproteins; MS: Mass spectroscopy; MESI: Methanol extract of S.indicus; MIC: Minimum inhibitory concentration; mg: Milligram; m: Meter; mm: Millimeter; p.o: Drug administered orally; RBCs: Red blood cells; SIE: Ethanol extract of S.indicus; SOD: Superoxide dismutase; \%: Percentage.

\section{REFERENCES}

1. Agrawal VS. Drug Plants of India. 1st ed. New Delhi: Kalyani Publishers;1997.

2. Kritikar KR, Basu BD. Indian Medicinal Plants. 2nd ed. Deharadun: International Book Distributors; 1999

3. Arya VS. Indian Medicinal Plants. Chennai: Orient Longman Limited;1997.

4. Varsha JG, Patel BG, Rana DG. Sphaeranthus indicus Linn.: A phytopharmacological review. Int J Ayurveda Res. 2010;1(4):247-53.

5. Dr. Bhattacharjee SK. Handbook of Medicinal Plants. Jaipur: Pointer Publishers;1998.
6. Dr. Pandey G. Dravyaguna Vijnana. Ist ed. Varanasi: Krishnadas academy oriental Publishers \& Distributors;2001.

7. Chatterjee A, Pakrashi SC. The Treatise on Indian Medicinal Plants. New Delhi: Publications \& Information Directorate CSIR; 2003.

8. Bhakat A, Saha S. A critical review of Mundi (Sphaeranthus indicus Linn.). Int Ayurvedic Medical J. 2018;6(6):1279-83.

9. Singh S, Semwal BC, Gurulingappa NS. Microscopic and physicochemical evaluation of leaves of Sphaeranthus indicus Linn. Pharmacog J. 2017;9(1):21-6.

10. 10. Makhiia IK, Richard L, Kirti SP, Saleemullah K, Jessy M, Ammie M Sphaeranthus indicus: A Review of its chemical, pharmacological and ethnomedicinal properties. International J Pharmacol. 2011;7(2):171-9.

11. Chopra RN, Nayar SL, Chopra IC. Glossary of Indian Medicinal Plants. New Delhi: Publications \& Information Directorate, CSIR;1956.

12. Prof. (Mrs.) Chatterjee A, Dr. Pakrashi SC. The Treatise on Indian Medicinal Plants. New Delhi: National Institute of Sciences Communication \& Information resources, CSIR;2003.

13. Smt. Ramachandran K, Shri Kashyapa K, Shri Chand R. The useful plants of India. New Delhi: Publications \& Information Directorate, CSIR;1994.

14. Nadkarni AK. The Indian Materia Medica. Mumbai: Bombay Popular Prakshan Pvt. Ltd; 2002(vol 1).

15. Kapoor LD. Handbook of Ayurveda Medicinal Plants. US: CRC Press;2005

16. Dymock W, Warden CJH, Hooper D. Pharmacographia Indica. Delhi: Jayyed Press;1891.

17. Mishra BB, Yadav SB, Singh RK, Tripathi V. A Novel Flavonoid C-glycoside from Sphaeranthus indicus L. (Family Compositae). Molecules. 2007;12:2288-91.

18. Basu NK, Lamsal PP. A Chemical investigation of Sphaeranthus indicus Linn. Journal of the American Pharmaceutical Association. 1946;35(9):274-5

19. Sohoni JS, Roiatkar SR, Kulkarni MK, Dhaneshwar NN, et al. A new eudesmenolide and 2-hydroxycotic acid from Spheranthus indicus Linn, X-Ray molecular structure of $4 \alpha, 5 \alpha$-epoxy-7 $\alpha$-hydroxyeudesmanolide. J. Chem. Soc Perkin Trans. 1988:157-60.

20. Kaul PN, Rajeswara Rao BR, Bhattacharya AK, Singh K, Mallavarapu GR Ramesh S. Essential oil composition of Sphaeranthus indicus L. J Essential Oi Res. 2005;17(4):453-4.

21. Lodha V. Chemical analysis of the essential oil of Sphaeranthus indicus: An Ayurvedic plant of India. Indian Perfumer. 2003;47:29-30.

22. Singh SK, Saroj KM, Tripathi VJ, Singh AK, Singh RH. An antimicrobial principle from Sphaeranthus indicus L. (Family Compositae). International J Crude Drug Res. 2008;26(4):235-9.

23. Jadhav, Sonawane RB, Deshpande KB, Rojatkar NR, Supada R. Two new eudesmanolides from Sphaeranthus indicus (Linn.). Indian J Chemistry-B. 2004;46B(2):379-81.

24. Jadhav RB, Sonawane KB, Panse GT, Rojatkar SR. A new eudesmanolide from Sphaeranthus indicus. (Linn.). Indian J Chemistry-B. 2004;43B:217-8.

25. Rjatkar SR, Nagasampagi BA. 7-hydroxyeudesmanolides from Sphaernanthus indicus, Phytochemistry.1992;3(199):3270-1.

26. Mishra BB, Kisore N,Tiwari VK. A new antifungal eudesmanolide glycoside isolated from Sphaeranthus indicus Linn. (Family Compositae). Natural Product Research. 2016:1-7.

27. Pujar PP, Sawaikar DD, Rojatkar SR, Nagasampagi BA. Eudesmanods from Sphaernahus indicus. Fitoterapia. 2000;71(3):264-8.

28. Yadava RN, Kumar S.A novel isoflavone glycoside from the leaves of Sphaernahtus indicus. Fitoterapia. 1999;70(2):127-9.

29. Atta-Ur-Rahman, Shekhani MS, Perveen S, Habib-Ur-Rehamn, Yasmin A, Atiya Zia-UI-Haque, Shaikh D. 7-hydroxyfrullanolide, an antimicrobial sesquiterpene lactone isolated from S. indicus Linn. J Chem Res. 1989.

30. Rastogi RP. Mehrotra BN. Compendium of Indian Medicinal plants. New Delhi Publications and Information, CSIR;1993.

31. Varsha JG, Bharatkumar GP. Effect of hydroalcoholic extract of Sphaeranthus indicus against experimentally induced anxiety, depression and convulsions in rodents. Int J Ayurveda Res. 2010;1(2):87-92.

32. Ambavade SD, Mhetre NA, Tate VD, Bodhankar SL. Pharmacological evaluation of the extracts of Sphaeranthus indicus flowers on anxiolytic activity in mice. Ind J Pharmacol. 2006;38(4):254-9.

33. Galani VJ, Patel BG. Psychotropic activity of Sphaeranthus indicus Linn.in experimental animals. Pharmacog Res. 2009;1(5):307-13.

34. Digambar BA, Guru Prasad M. Evaluation of neuropharmacological activity of petroleum ether, methanolic and aqueous extracts of flower heads of Sphaeranthus indicus in mice. J Applied Pharmaceutical Sci. 2014;4(4):112.

35. Mhetre NA, Amdavade SD, Bodhankar SL. Neuroleptic activity of extracts of Sphaeranthus indicus in mice. Ind J Natural Products. 2006;22(2):24.

36. Nanda BK, Jena J, Rath B, Behera B. Anticonvulsant activity of whole parts of Sphaeranthus indicus Linn. extract in experimental mice. Drug Invention Today.2010;2(3):202 . 
37. Bafna AR, Mishra SH. Immunomodulatory activity of petroleum ether extract of flower heads of Sphaeranthus indicus Linn. J Herb Pharmacother. 2007;7(1):25 37.

38. Anarthe SJ, Malavika E, Pravalika A,Ganga raju M. Screening of immunomodulatory activity of Sphaeranthus indicus Linn. whole plant. J Pharmacy and Biological Sci. 2015;10(6):91-9

39. Jawalkar PD, Bhujbal SS, Bafna AR. Immunomodulatory activity of herbal formulation (CE1 and CE2) containing Sphaeranthus indicus, Curculigo orchioides and Piper nigrum. International J Pharmaceutical and Chemial Sci. 2014;3(1).

40. Shekhani MS, Shah Muazzam P, Yasmin A, Siddiqui R, Perveen S, Mohammed Khan $\mathrm{K}$, et al. An immunostimulant sesquiterpene glycoside from Sphaeranthus indicus. Phytochemistry.1990;29(8):2573-6.

41. Thota SP, Jadhav M, Kumar K, Venuganti A, Devi M, Vadiari S, Mittapeli G. Studies on in vitro antioxidant and antibacterial activities of Sphaeranthus indicus (Linn). International J of Pharmaceutical Research and Biomedical analysis. 2013;2(1):1-9.

42. Kavitha KS, Satish S. In vitro antioxidant and antimicrobial activities of Sphaeranthus indicus $\mathrm{L}$. Journal of Biologically active products from Nature. 2015;5(2):163-71.

43. Ramachandran S, Kumar AK, Maheswari MU, Ravi TK, Sivashanmugam AT, Sarvanan S, et al. Investigation of antidiabetic, antihyperlipidemic and in vivo antioxidant properties of Shaeranthus indicus linn. in type I diabetic rats: an identification of possible biomarkers. Evidence-based Complementary and Alternative Medicine. 2011.

44. Malairajan P, Venu Babu G, Saral A, Mahesh S, Gitanjali. Anti-ulcer activities of Sphaeranthus indicus Linn. International J Drug Development \& Res. 2013;5(1):43-6.

45. Pande VV, Dubey S. Antihyperlipidemic activity of Sphaeranthus indicus on atherogemic diet induced hyperlipidemia in rats. International J of Green Pharmacy. 2009;3(2).

46. Tupkari SV, DeoreTK, Sarpate RV. Bronchodilatory effect of Sphaeranthus indicus Linn against allergen induced bronchospasm in guinea pigs. Pharmacognosy Magazine. 2009;5(19):74-7.

47. Arivoli S, John Ravindran K, Tennyson S. Larvicidal Efficacy of Plant Extracts against the malarial Vector, Anopheles stephensi Liston (Ditpera: Culicidae). World J Medical Sci. 2012;7(2):77-80.

48. Kovendan K, Airvoli S, Maheshwaran R, Barkar K, Vincent S. Larvicidal efficacy of Sphaeranthus indicus, Cleistanthus collinus and Murraya koenigii leaf extracts against filarial vector Culex quinquefasciatus Say (Diptera: Culicidae). Parasitol Res. 2012;111(3):1025-35.

49. Adam A, Syed Baqir shyum N, Shahnaz G, Rehana S. Anti-inflammatory and analgesic activites of ethanolic extract of Sphaeranthus indicus Linn. Pakistan J Pharmaceutical Sci. 2011;24(3):405

50. Meheri BR, Rath BG, Biswal S. Evaluation of anti-inflammatory activity of ethanolic extract of Sphaeranthus indicus. J Chem Pharm Res. 2011;3(3):831-4.

51. Nanda BK, Jena J, Rath B, Behera B. Anti-inflammatory activity of whole plant of Sphaeranthus indicus Linn. Der Pharmacia Lettre. 2(1):181-8.

52. Srivastava RA, Mistry S, Sharma S. A novel anti-inflammatory natural product from Sphaeranthus indicus inhibits expression of VCAM1 and ICAM1 and show atherosclerosis progression independent of lipid changes. Nutr Metab (Lond.). 2015:12-20.

53. Nanda BK, Jena J, Rath B, Behera BR. Analgesic and Antipyretic activity of whole parts of Sphaeranthus indicus Linn. Journal of Chemical and pharmaceutical Research. 2009;1(1):207-12.

54. Malairajan P, Venu Babu G, Saral A, Gitanjali. Analgesic activity of Sphaeranthus indicus Linn. International Journal of Drug Development and Research. 2012;494:130-2.

55. Prabhu KS, Lobo R. Antidiabetic properties of the alcoholic extract of Sphaeranthus indicus in streptozotocin-nicotinamide diabetic rats. Journal of Pharmacy and Pharmacology. 2008;60(7):909-16.
56. Kharkar R, Parwar DP, Shamkumar, Prashant B. Anti-diabetic activity of Sphaeranthus indicus Linn. extracts in alloxan-induced diabetic rats International J Pharmacy and Pharmaceutical Sci. 2013;5(2):524.

57. Kappera S, Dr. MGR. Antidiabetic and hypolipidemic activity of methanolic extract of Sphaeranthus indicus in alloxan induced diabetic rats. Indo American J Pharmaceutical Res. 2014;49(11):5218-25.

58. Jha RK, Mangilal, Bhandari A, Nema R K. Antidiabetic activity of flower head petroleum ether extracts of Sphaeranthus indicus Linn. Asian J Pharmaceutical and Clinical Res. 2010;3(10):16-9.

59. Mathew JE, Srinivasan KK, Dinakaran V, Joseph A. Mast cell stabilizing effects of Sphaeranthus indicus. J Ethnopharmacol. 2009;122(2):394-6.

60. Sundari K, Govindaraju G, Bharathi B. Hepatoprotective effect of ethanolic extracts of Sphaeranthus indicus (Linn) on paraetamol-induced liver toxicity in rats. International J Applied Biology and Pharmaceutical Tech. 2011;2(2):315-21.

61. Gowri R, Madhavan V. Hepatoprotective activity of aqueous extract of Sphaeranthus indicus against paracetamol induced hepatotoxicity in rats. MSRUAS-SASTECH Journal. 2016;13(2):21-4.

62. Lizby AM, Dhanyaraj D, Prathibhakumari PV, Prasad V. Hepatoprotective and antioxidant potential of Spaeranthus indius (Linn.) on liver damage in wistar rats. International J Pharmacy and Pharmaceutical Sci.2012;4(3):2225.

63. Mohommedu Hasan MG, Paheerathan V. Evaluate the Effectiveness of sphaeranthus indicus linn on the Management of Constipation. International $J$ Advanced Ayurveda and Integrative Med. 2015;1(1):1-12.

64. Mathew Nisha, Kalyanasundaram M, Paily KP, Abidha, Vanamail P, Balaraman B. In vitro screening of medicinal plant extracts for macrofilaricidal activity. Parasitol Res.

65. Jha RK, Garud N, Nema RK. Excision and incision wound healing activity of flower head alcoholic extract of Sphaeranthus indicus Linn. in albino rats. Global J Pharmacol. 2009;3(1):32-7.

66. Sadaf F, Saleen R, Ahmed M, Ahmad SI, Navaid-ul-Zafar. Healing potential of cream containing extract of Sphaeranthus indicus on dermal wounds in guinea pigs. J Ethnopharmacol. 2006;107(2):161-3.

67. Malairajan P, Venu Babu G, Saral A, Mahesh S, Gitanjali. Anti-ulcer activities of Sphaeranthus indicus Linn. International J Drug Development and Res. 2013;5(1):43-6.

68. Duraipandiyan V, Kannan P, Ignacimuthu S. Antimicrobial activity of Sphaeranthus indicus L. Ethnobotanical Leaflets. 2009;13:320-5.

69. Thakur R, Singh R, Jain N. Evaluation of antibacterial activity of Sphaeranthus indiucs L. leaves. J Pharmacy Res. 2012;5(8):4382-8.

70. Meheri BR, Mahar S, Rath BG, Sahoo SK. Antimicrobial activity of ethanolic extracts of leaves of Sphaeranthus indicus. Der Pharmacia Lettre. 2013;5(1):810.

71. Irfani M, Ahmed S, Sharma M. Antimicrobial activity of terpenoids from Sphaeranthus indicus L. Asian J Plant Science and Res. 2014;4(1):1-6.

72. Mishra BB, Kishore N, Tiwari VK. A new antifungal eudesmanolide glycoside isolated from Sphaernathus indicus Linn. (Family Compositaae). Nat Prod Res. 2016;8:1-7.

73. Sharanya M, Oviya IR, Poornima V, Jeyam M. Antifungal susceptibility testing of few medicinal plant extracts against Aspergillus spp. and Microsporum sp. J Applied Pharmaceutical Sci. 2013;3(8):512-6.

74. Nanda BK, Jena J, Rath B, Behera BR, Sahu A. Antidiarrhoel activity of Sphaeranthus indicus Linn. extract. J Pharmacy Res. 2010;3(3):627-30.

75. Mane MN, Badole SL. Sphaeranthus indicus: Skin disease preventive plant Bioactive Dietary Factors and Plant extracts in Dermatology. 2012:445-9.

76. Nahata A, Saxena A, Suri N, Saxena AK, Dixit VK. Sphaeranthus indicus induces apoptosis through mitrochondrial-dependent pathway in HL-60 cells and exerts cytotoxic potential on several human cancer cell lines. Integr Cancer Ther 2013;12(3):236-47.

77. Shakila Ramachandran. Review on Sphaeranthus indicus Linn. (Ko - aikkarantai). Pharmacogn Rev. 2013;7(14):157-69. 


\section{GRAPHICAL ABSTRACT}

\section{Sphaeranthus indicus Linn.} (Asteraceae)

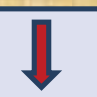

\section{Geographical source: Aromatic herb; Rater of Chhindwara} District, M.P

\section{Phytochemical compounds}

Spaeranthine, eudesmenolide-7 $\alpha$-hydroxy eudesm-4-en-6, 12-olide, 2-hydroxycostic acid, $\beta$ eudesmol, ilicic acid, methychavicol, $\alpha$-ionone, d-cadinene, $\alpha$-terpinene, citral, geraniol, geranyl acetate, sphaerene, indicusene and sphaeranthol.

\section{Pharmacological activity}

Anxiolytic activity, Neuroleptic activity, Immunomodulatory effect, Antioxidant activity, Antiulcer activity, Antihyperglipidemic activity, Bronchodilator activity, Larvicidal activity, Antiinflammatory, Analgesic activity, Antidiabetic activity, Mast cell stabilizing effect, Hepatoprotective activity, Laxative activity, in vitro macrofilaricidal activity, Antimicrobial activity

\section{SUMMARY}

The reviewed manuscript requires more informative research which can explore their proper applications. It needs to add more updated pharmacological activities to enhance the broad spectrum of therapeutic usage to be considered for new drug formulations.

\section{ABOUT AUTHORS}

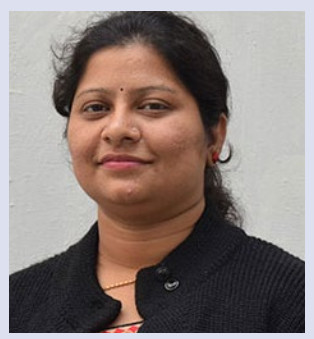

\section{Mrs. Sonia Singh}

Assistant Professor

M.Pharm (GLA University, Mathura)

She had an experience of about 12 years of teaching in the GLA University, Mathura. She has written about more than 20 papers, including review and research in the field of herbs and pharmacognosy. She also attended many national workshops. She has completed her graduation in pharmacy in the year of 2005 and post-graduation in 2008 from Rajiv Gandhi Institute of Health Science, Karnataka. Now She is pursuing her PhD from GLA University, Mathura U.P.

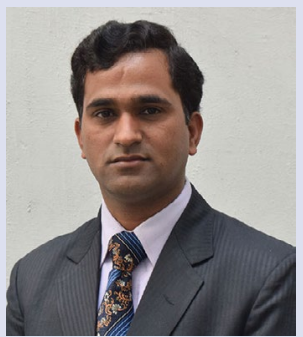

\section{Mr. Bhupesh C. Semwal}

Assistant Professor

M.Pharm (GLA University, Mathura)

$\mathrm{He}$ is accomplished as a teacher \& researcher in the field of Pharmacology. He has more than twelve years of teaching as well as research experience. He authored more than 15 research articles in several national and international journals. He also attended UGC sponsored workshop and given presentation in more than 15 national and international conferences in India and abroad. He has completed his B. Pharm in 2004 and M. Pharm in 2006 in Pharmacology. Even he has guided more than 20 post graduate students. 


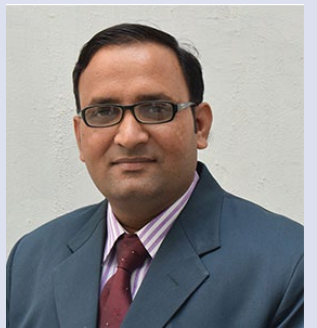

\section{Dr. Prabhat Kr. Upadhyay}

Associate Professor

$\mathrm{PhD}$ (GLA University, Mathura)

He passed M. Pharm. from Rajiv Gandhi University of Health Sciences in 2006, Bangalore. He has been awarded Ph. D in 2018 and working as Associate Professor, in Institute of Pharmaceutical Research, GLA University, Mathura, Uttar Pradesh. He has total experience of teaching and research more than 13 years. He has guided more than 25 undergraduate and 8 post graduate students; two Ph. D scholars are working with him. He has published total 25 papers of national and international repute. He is the life member of various associations. He is reviewer of various national and international journals.

Cite this article: Singh S, Semwal BC, Kr Upadhaya P. Pharmacognostic study of Sphaeranthus indicus Linn.: A Review. Pharmacog J. 2019;11(6):1376-85 